\title{
SOLUSI DESAIN GEDUNG PUSAT ONKOLOGI RSUP Dr. KARYADI SEMARANG TERHADAP MASALAH INTEGRASI PELAYANAN MEDIS
}

\author{
Sri Hartuti Wahyuningrum ${ }^{1}$ ) Bintang Noor Prabowo ${ }^{2}$ ) Mustika K Wardhani ${ }^{3 *}$ )
}

*) Corresponding author email : kweemustika@gmail.com

\author{
1) Departemen Arsitektur, Fakultas Teknik, Universitas Diponegoro,Semarang - Indonesia \\ 2) Norges Teknisk Natuvitenskapnkapelige Universteit, Trondheim - Norway \\ Program Studi Infrakstruktur Teknik Sipil dan Arsitektur, Sekolah Vokasi, Universitas Diponegoro - Indonesia \\ 3) Research Organization of Open Inovation and Collaboration, OIC Ritsumeikan University, Osaka, Jepang
}

\author{
Article info \\ MODUL vol 19 no 2, issues period 2019 \\ Doi $\quad: 10.14710 / \mathrm{mdl} .19 .2 .2019 .85-94$ \\ Received : 24th august 2019 \\ Revised : : 10th september 2019 \\ Accepted : 15th november 2019
}

\section{Abstrak}

Kebutuhan akan pelayanan Radioterapi dan Onkologi di RSUP Dr. Kariadi dari tahun ke tahun semakin meningkat dengan dimilikinya alat seperti Brakiterapi dan Cobalt ( 2 macam/unit) serta LINAC pada saat ini sudah menyebabkan pelayanan bagi yang membutuhkan pengobatan dengan radioterapi maupun pelayanan terhadap penderita kanker masih memerlukan antrian yang panjang. Dari kebutuhan yang mendesak tersebut terlihat bahwa bangunan atau fasilitas untuk Onkology Center sebagai bentuk pelayanan untuk penyakit kanker yang komprehensif sangat diperlukan. Karakteristik bangunan ini menjadikannya perlunya kajian terhadap persyaratan utama dalam perancangan bangunan fasilitas kesehatan khusus yang terpadu. Korelasi yang jelas antara keperluan pemenuhan fungsional pelayanan dengan penyelesaian desain sangat diperlukan. Yaitu terkait penempatan fasilitas utama dan ruang lainnya yang terkait, persyaratan teknis khusus untuk tindakan perawatan (treatment) maupun penanganan kondisi pasien dan penyelesaian finishing ruang. Hasil penelitian dapat digunakan sebagai panduan dalam proses perancangan arsitektur untuk perancangan bangunan spesifik terutama untuk bangunan Rumah Sakit melalui kajian terhadap integrasi persyaratan medik dalam implementasi desain arsitektur pada bangunan khususnya untuk bangunan Gedung Onkology Center yang spesifik, sehingga akan membantu menemukenali perancangan yang bersifat komprehensif.

Keywords: Integrasi, Persyaratan Medik, Desain Arsitektur, Gedung Pusat Onkologi

\section{PENDAHULUAN}

Kebutuhan akan pelayanan Radioterapi dan Onkologi di RSUP Dr. Kariadi dari tahun ke tahun semakin meningkat dengan dimilikinya alat seperti Brakiterapi dan Cobalt (2 macam/unit) serta LINAC pada saat ini sudah menyebabkan pelayanan bagi yang membutuhkan pengobatan dengan radioterapi maupun pelayanan terhadap penderita kanker masih memerlukan antrian yang panjang.

Meskipun pada akhir tahun 2014 dan awal tahun 2015 peningkatan sistem pelayanan yang menggunakan peralatan ini sudah dikembangkan sampai melakukan pelayanan malam hari yang terbagi dalam beberapa shift serta dengan sistem penjadwalan pasien yang akan mendapat terapi sehingga secara signifikan meningkatkan jumlah layanan. Termasuk penambahan fasilitas bunker COBALT dan LINAC yang dilaksanakan pembangunan fisiknya pada tahun 20152016 menyebabkan sangat mendesaknya pembangunan Gedung Radioterapi dan pusat onkologi RSUP Dr. Kariadi Semarang dalam tahun 2016 yang lalu.

Karakteristik bangunan ini menjadikannya perlunya kajian terhadap persyaratan utama dalam perancangan bangunan fasilitas kesehatan yang terpadu. Pemahaman terhadap perancangan desain arsitektur yang dapat menjawab persoalan yang komprehensif khusunya untuk perancangan bangunan pelayanan kesehatan kadang masih terkendala kurang terintegrasinya persyaratan medik ke dalam perancangan desain arsitektur (Sabarudin, 2013) (Hatmoko et al, 2015).

Mengingat perancangan arsitektur dalam konteks kegiatan pembangunan sarana dan prasarana akan menjadi acuan bagi perancangan di bidang lainnya yang menunjang yaitu bidang struktur/sipil, bidang mekanikal elektrikal dan sanitasi, dan lainnya sesuai lingkup bangunan yang didesain (Fischer \& Mauser, 2009) (Lasau \& Tice, 1992). 
Untuk itu pemahaman terkait integrasi persyaratan medik dan implementasinya dalam penyelesaian desain arsitektur menjadi penting, studi kasus yang diambil adalah Desain Gedung pusat onkologi RSUP Dr. Kariadi Semarang yang memuat adanya keterpaduan berbagai bentuk pelayanan maupun tindakan bagi penderita penyakit kanker sehingga dapat diharpkan memberikan peluang yang lebih baik bagi kesembuhan pasien.

\section{STUDI LITERATUR}

\section{Pelayanan Radioterapi}

Mandat dari program kesehatan manusia IAEA berasal dari Pasal II dari statutanya, yang menyatakan bahwa IAEA akan berusaha untuk mempercepat dan memperbesar kontribusi energy atom untuk perdamaian, kesehatan dan kemakmuran di seluruh dunia. Tujuan utama dari program kesehatan manusia adalah untuk meningkatkan kemampuan negara-negara anggota IAEA dalam menangani masalah yang berkaitan dengan pencegahan, diagnosis dan pengobatan masalah kesehatan melalui pengembangan dan penerapan teknik nuklir, dalam kerangka jaminan mutu (IAEA, 2014).

\section{Pelayanan Onkologi}

Pelayanan onkologi adalah pelayanan terapi terhadap penyakit kanker yang secara teknis merupakan bentuk pelayanan yang sifatnya terpadu mengingat kompleksitas dan karakteristik penyakit tersebut. Pelayanan kemoterapi mempunyai beberapa karakteristik terkait tata cara pemberian pengobatan jenis kemoterapi dan prosedur pemberian yaitu untuk jenis kemoterapi siklus pendek yaitu 2-4 jam pemberian, kemoterapi intra tekal dan kemoterapi siklus panjang dengan masa pelaksanaan pemberian lebih dari 6 jam.

Menurut Badan Internasional untuk Penelitian Kanker dan Organisasi Kesehatan Dunia WHO, jumlah dari kasus kanker baru terdeteksi setiap tahun di seluruh dunia diperkirakan akan meningkat, terutama di negara berpenghasilan rendah dan menengah. Lebih dari setengah dari semua pasien kanker akan membutuhkan radioterapi sebagai bagian dari manajemen penyakit mereka. Radioterapi merupakan bidang multidisiplin yang menggunakan teknologi yang kompleks memanfaatkan sumber radiasi untuk pencitraan dan pengobatan pasien kanker.

Dengan demikian, fasilitas radioterapi memerlukan ruangan khusus terlindung, perencanaan yang matang dan desain khusus untuk memastikan bahwa ruangan tersebut tidak hanya memberikan perlindungan radiasi, tetapi juga mengoptimalkan alur kerj (VA Design Guide-Nuclear, 2008)..a.

3. Pelayanan Radioterapi di RSUP Dr. Kariadi Semarang

RSUP Dr. Kariadi Semarang sebagai rumah sakit rujukan nasional mempunyai tanggung jawab yang besar terhadap permasalahan penanganan bagi pasien kanker dan lainnya yang terkait, untuk itu dengan embrio pelayanan Radioterapi yang sudah dimiliki maka akan dikembangkan Pusat Pelayanan Radioterapi dan Onkologi di RSUP Dr Kariadi Semarang.

Lokasi dan peletakan fasilitas radioterapi dalam lingkungan rumah sakit membutuhkan pertimbangan yang cermat karena peran onkologi radiasi dalam pengelolaan kanker multidisiplin, termasuk persyaratan untuk diagnosis, rujukan yang terkoordinasi dan tindak lanjut jangka panjang dari pasien. Pembangunan bunker (ruang terlindung) khusus untuk menempatkan peralatan pengobatan secara teknis merupakan tantangan bagi ahli teknik dan kebutuhan pengawasan profesional untuk memastikan integritas struktural jangka panjang.

Karena proses radioterapi berkaitan erat dengan fungsi staf utama, detail dari desain internal fasilitas penting untuk mencapai ergonomi tempat kerja yang sehat dan untuk memfasilitasi alur kerja. Oleh karena itu, keseluruhan konsep desain harus terdiri dari lima area fungsional utama yang mempercepat alur kerja radioterapi. Area-area fungsional dalam radioterapi adalah area penerimaan dan konsultasi klinis, area pencitraan dan daerah perencanaan pengobatan, dan dua area perawatan (teleterapi dan brachytherapy).

Penempatan area-area ini harus disesuaikan dengan situs yang diusulkan dan praktek lokal yang dipilih. Namun, harus mempercepat pergerakan staf dan pasien yang lebih luas, konsultasi dan komunikasi.

Secara klinis fisikawan medis yang memenuhi syarat bertanggung jawab untuk memastikan bahwa perhitungan perlindungan didasarkan pada perkiraan yang dapat diterima dari beban kerja, penggunaan dan faktor-faktor okupansi, dan bahwa desain mengakomodasi alur kerja klinis yang diinginkan. Selain itu, pelaksanaan teknik baru dan teknologi masa depan juga harus dipertimbangkan. Regulator keselamatan radiasi nasional diberi mandat untuk menyetujui desain akhir sebelum konstruksi dan untuk member ijin fasilitas sebelum dimulainya perawatan pasien.

Hal-hal teknis yang menjadi pertimbangan untuk pengembangan Pelayanan Radioterapi dan Onkologi diantaranya meliputi : 
a. Ketersediaan Lahan: lahan yang tersedia harus terintegrasi dengan bagian lain yang terkait atau dengan mengembangkan fasilitas eksisting yang sudah ada dan akan tetap dimanfaatkan sehingga lebih efisien (K. Schleifer,2010).

b. Kondisi geoteknik: kondisi daya dukung tanah yang memadai terutama terkait dengan kemampuan mendukung beban berat dari fasilitas bunker maupun bahaya radiasi yang mungkin timbul

c. Penyediaan Listrik: ketersediaan daya listrik yang besar menyesuaikan fasilitas yang diakomodasi dan penanganan darurat pada saat listrik padam.

d. Perlindungan Kebakaran: adanya proteksi terhadap bahaya kebakaran baik yang bersifat pasif maupun aktif, yaitu melingkupi keamanan terhadap pasien maupun perlengkapan peralatan yang peka terhadap panas.

e. Ketersediaan Tenaga: tersedianya tim untuk operasional perlengkapan dan pelayanan yang harus disinkronkan dengan proses pengadaan perlengkapan fisik baik bangunan maupun jenis perlatannya.

f. Jenis dan Macam Pelayanan: jenis pelayanan atau ruang diperlukan dalam aplikasinya pada pembangunan gedung pelayanan tersebut misal ruang kemoterapi, farmasi (khususnya untuk mixing/handling obat sitostatika), rawat inap dan ruang isolasi bagi pasien imunitas menurun.

\section{MATERIAL DAN METODE}

Pada dasarnya penelitian menggunakan metoda deskriptif, yang dijalankan dalam empat tahap kegiatan, sebagai berikut:

\section{Tahap 1 - Observasi}

Merupakan kegiatan survai, yang mencakup survai lapangan (primer dan sekunder), khususnya untuk obyek yang menjadi studi kasus dalam penelitian ini yaitu Hasil Perencanaan Gedung Onkology Center RSUP Dr. Kariadi dan survai data sekunder serta kajian referensi.

Observasi dilakukan pada awal kegiatan untuk mengidentifikasi konsep perencanaan dan kaitannya dengan kesesuaian fasilitas yang diintegrasikan dalam bangunan.

Output proses ini adalah teridentifikasinya jenis ruang yang diperlukan, korelasi antar fungsi ruang dan kelengkapan ruang terkait persyaratan medik yang diperlukan sehingga dapat memenuhi pelayanan kesehatan yang diharapkan.

2. Tahap 2 - Dokumentasi

Sebagai bentuk pendeskripsian terhadap studi kasus yang dipilih dan penyelesaian teknis yang dilakukan terkait macam fasilitas dan persoalan pemenuhan kriteria serta persyaratan desain arsitektur yang diminta terkait dengan jenis pelayanan medik yang dilakukan pada Gedung Pusat Onkologi tersebut.

3. Tahap 3 - Kajian terhadap Jenis Ruang, Integrasi Ruang dan Pemenuhan Persyaratan Pelayanan Kesehatan pada Gedung Onkology Center RSUP Dr. Kariadi Semarang

Analisis, menggunakan metoda saintifik, berkenaan dengan konfigurasi tata ruang dan persyaratan teknisnya dalam menunjang pelayanan medik khusus terutama terkait prosedur pelayanan (treatment) kepada pasien dengan penyakit kanker dalam ruang tersebut pada obyek studi kasus.

Pada tahap ini eksplorasi desain terhadap macam dan jenis ruang, integrasi antar ruang dan pemenuhan persyaratan teknis bangunan akibat prosedur pelayanan medik yang diberikan , penyelesaian kelengkapan bangunan untuk memberikan pelayanan yang terintegrasi untuk untuk pemenuhan persyaratan teknis terhadap fungsi kinerja ruang.

4. Tahap 4 - Kesimpulan dan Rekomendasi Kesimpulan disusun setelah hasil analisis yang berupa keterkaitan jenis ruang yang harus disediakan, integrasinya dalam pelayanan dan yang menunjang terakomodasinya pelayanan medik khusus untuk penderita kanker pada bangunan Gedung Onkology tersebut.

Dengan demikian rekomendasi dapat diberikan sebagai panduan desain untuk mendukung pemahaman terhadap peran penting pemahaman terhadap jenis ruang atau fasilitas yang terintegrasi serta memenuhi persyaratan teknis medik yang spesifik.

Untuk lebih jelasnya dapat dilihat pada skema 1 berikut ini:

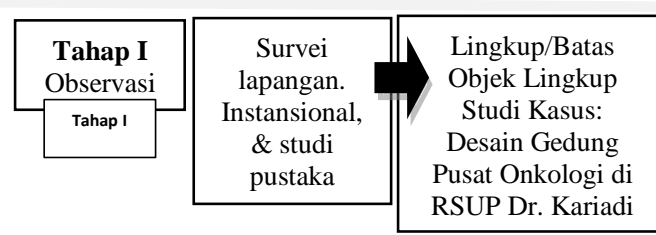

\begin{tabular}{|c||c||c|}
\hline $\begin{array}{c}\text { Tahap 2 } \\
\text { Dokume } \\
\text { ntasi }\end{array}$ & $\begin{array}{c}\text { Penyusunan } \\
\text { data-data } \\
\text { fasilitas/jenis } \\
\text { ruang, korelasi } \\
\text { antar ruang \& } \\
\text { syarat teknis } \\
\text { pelayanan } \\
\text { medik }\end{array}$ & $\begin{array}{c}\text { Persyaratan } \\
\text { Teknis ruang } \\
\text { pusat Onkologi } \\
\text { (syarat khusus) \& } \\
\text { pelayanan } \\
\text { komprehensif }\end{array}$ \\
\hline
\end{tabular}




\begin{tabular}{|c|}
\hline Tahap 3 \\
Kajian Macam \\
dan jenis \\
Ruang, \\
Integrasinya \& \\
Pemenuhan \\
Kriteria \\
Teknis \\
\hline
\end{tabular}

\begin{tabular}{|l|c|}
\hline \multicolumn{1}{|c|}{ Identifikasi: } & Kajian ragam \\
1. Macam/Jenis & ruang, \\
Ruang untuk & integrasinya \& \\
fasilitas Onkologi & persyaratan \\
Center & teknis yang \\
2. Tata Ruang dan & mendukungnya \\
Integrasi & \\
pelayanan & \\
3. Pemenuhan & \\
Persyaratan & \\
Teknis Pelayanan & \\
Medik & \\
\end{tabular}

\begin{tabular}{|c||c|c|}
\hline $\begin{array}{c}\text { Tahap 4 } \\
\text { Kesimpulan \& } \\
\text { Rekomendasi }\end{array}$ & $\begin{array}{c}\text { Hal yang menjadi } \\
\text { penekanan } \\
\text { pertimbangan dalam } \\
\text { perancangan } \\
\text { bangunan yang } \\
\text { memberikan } \\
\text { pelayanan terpadu } \\
\text { pada kasus pasien } \\
\text { dengan penyakit } \\
\text { kanker }\end{array}$ & \\
\hline
\end{tabular}

Figur 1. Bagan Alur Metodologi Pelaksanaan Kegiatan

\section{ANALISA}

\section{Studi Kasus}

Studi kasus ditentukan berdasar pertimbangan adanya variasi karakteristik bentuk rumah sakitnya, sebagai contoh untuk pemilihan terhadap RSUP Dr. Kariadi, merupakan rumah sakit pemerintah yang besar di Semarang dan menjadi rumah sakit rujukan. Karakter tata bangunan yang ada pada awalnya merupakan bangunan massa banyak dengan ketinggian lantai bangunan bervariasi antara 1 lantai sampai 3 lantai namun kemudian pembangunan yang lebih sekarang sudah berorientasi pada bangunan berlantai banyak.

Rumah Sakit Dr. Kariadi mempunyai Instalasi Kedokteran Nuklir yang didalamnya akan menyediakan sarana untuk Terapi Ablasi yaitu terapi pemberian obat berupa Yodium 133 ( I-133) yang mempunyai efek adanya pancaran radiasi dari pasien yang meminum obat tersebut selama 4-5 hari setelah meminum obat tersebut. Obat yodium 133 digunakan untuk penanganan pasien dengan penyakit pada kelenjar gondok (thyroid).

\section{Gedung Pusat Onkologi RSUP Dr. Kariadi}

Visualisasi Gedung pusat onkologi dan lingkungan sekitarnya, sebagai figure 1 berikut :
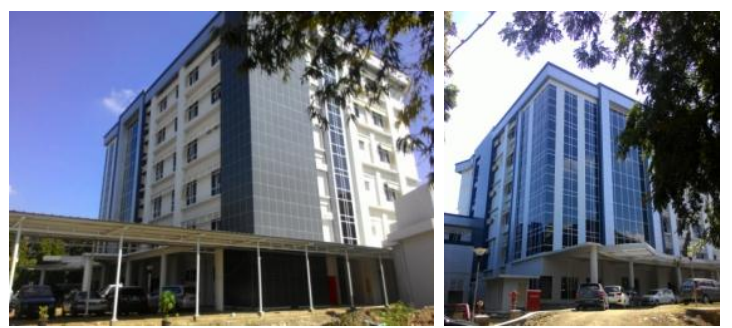

Figur 2. Visualisasi Gedung Pusat Onkologi

Tampilan bangunan Gedung Pusat Onkologi RSUP Dr. Kariadi dapat dilihat sebagai berikut baik dari sisi barat (yang terlihat dari J1 Dr. Soetomo maupun dari sisi selatan yang menghadap jalan
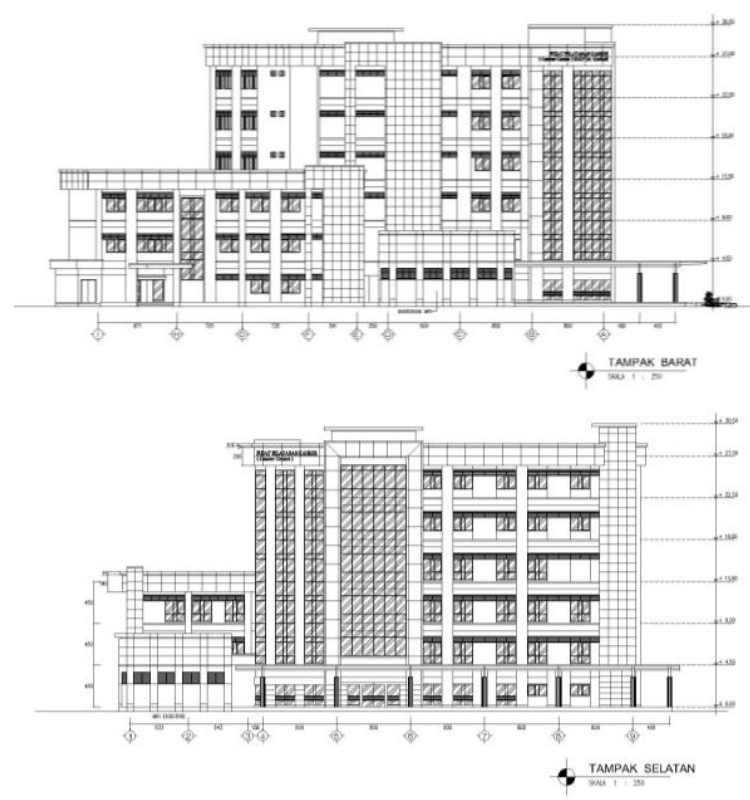

Figur 3. Tampak Bangunan Gedung Pusat Onkologi

\section{Gedung Pusat Onkologi RSUP Dr. Kariadi}

Mengingat fasilitas pelayanan Radioterapi dan Onkologi merupakan fasilitas yang relatif komprehensif dan mempunyai persyaratan tinggi ada beberapa hal yang harus diperhatikan dan mengacu referensi yang dapat digunakan sebagai dasar. Berikut Persyaratan Ruang khusus yang disajikan dalam tabulasi (lihat tabel 1)

Tabel 1. Persyaratan Ruang Khusus

\begin{tabular}{ccc}
\hline Ruang & Uraian Penjelasan \\
\hline R. Radioterapi & Merupakan & jenis \\
(Brakiterapi, & bunker beton yang \\
Cobalt dan & ukuran , konfigurasi \\
LINAC) & lay out dan korelasi \\
& antar ruang harus
\end{tabular}




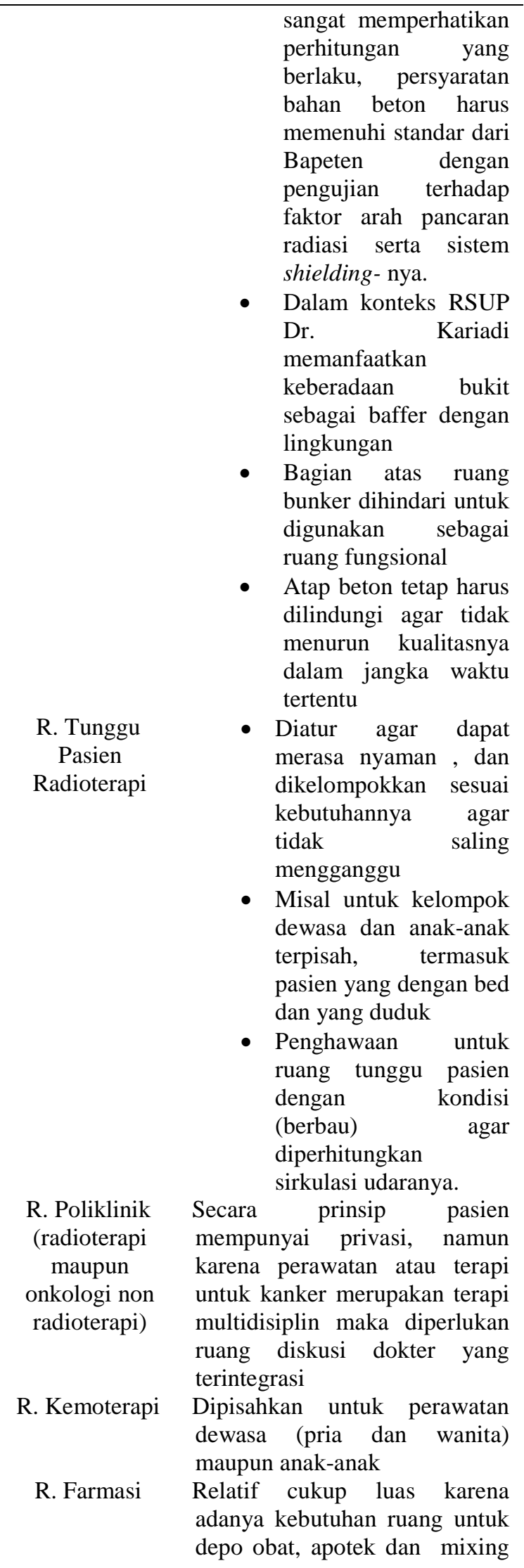

obat untuk kemoterapi dan lainnya

R. Rawat Inap Mengacu standar yang berlaku, jumlah pelayanan tiap lantai disesuaikan daya kemampuan pelayanan dari nurse station secara efektif ( tidak lebih dari 25-30 kamar)

Persyaratan Mengingat kebutuhan daya Listrik cukup besar terutama untuk pendukung operasional peralatan (seperti LINAC) maka disarankan untuk mempunyai gardu dan genset tersendiri

Ruang Umum Tampilan ruang umum secara keseluruhan bersifat tenang dan menimbulkan kenyamanan bagi pengguna terutama untuk ruang tunggu dan perawatan (one day care maupun rawat inap), pengolahan pada ruang terapi untuk menunjang kenyamanan juga diperlukan sehingga secara psikis akan mendukung pasien

Persyaratan Perlu dipertimbangkan untuk evakuasi manuver di area tangga evakuasi dan proteksi lift sebagai alternatif fire lift.

Penggunaan ramp evakuasi kurang memungkinkan pada area tersebut untuk itu sistem evakuasi agar dipertimbangkan secara komprehensif termasuk prosedur operasionalnya.

\section{Sumber : CV.Aretas, 2015}

\section{Konteks Lingkungan}

Pembangunan gedung pusat onkologi sudah seharusnya memperhatikan permasalahan kondisi eksisting yang ada di sekitar rencana bangunan, meskipun beberapa dilakukan pembangunan bertahap namun pembangunan yang terintegrasi tetap menjadi perhatian utama terutama dengan kondisi pada figur 4 yang cukup rapat. 


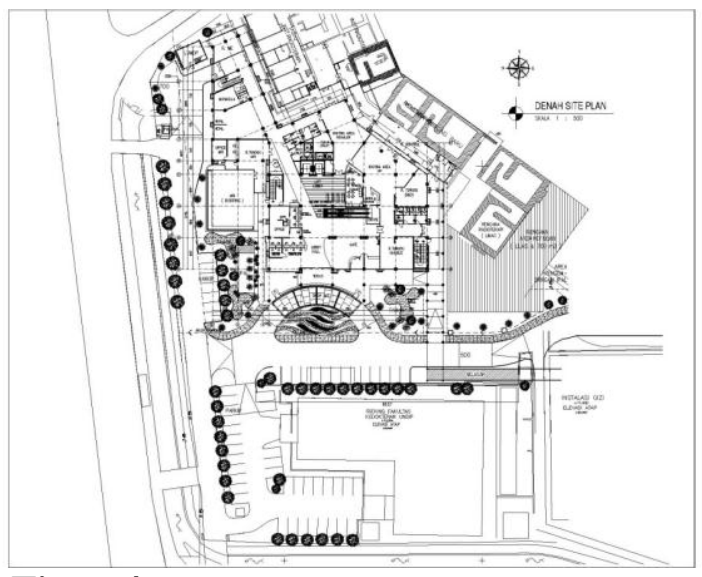

Figur 4. Plot Bangunan gedung pusat onkologi terkait Fasilitas Eksisting RSUP Dr. Kariadi (CV. Aretas, 2017)

Sedangkan pembahasan terkait peraturan K3 (Runchiman et al, 2009) yang minimal harus dipenuhi pada Gedung Pusat Onkologi RSUP Dr. Kariadi adalah sebagai table 2 berikut :

Tabel 2. Persyaratan K3

\begin{tabular}{lc}
\hline Persyaratan K3 & Keterangan \\
\hline $\begin{array}{c}\text { Setiap bangunan minimal } \\
\text { memiliki } 2 \text { akses } \\
\text { Keluar }\end{array}$ & Semua Lantai \\
Setiap pintu exit mengayun & Lantai Dasar, 1 dan \\
ke arah luar & \\
Pintu Tangga Darurat dapat \\
tertutup rapat
\end{tabular}

Bangunan dilengkapi dengan sistem proteksi bahaya kebakaran :

a. Instalasi hidrant gedung/luar (instalasi jenis outbow sehingga mudah perawatannya)

b. Instalasi Fire alarm

c. Smoke detector Sprinkler

Sumber : Tim K3 RSUP Dr. Kariadi-2015

\section{Gambar Pra Rancangan Bangunan Gedung Pusat Onkologi}

Adapun data denah bangunan maupun gambar pra rancangan lainnya sebagai data bangunan adalah rangkaian figur 5 sebagai berikut :

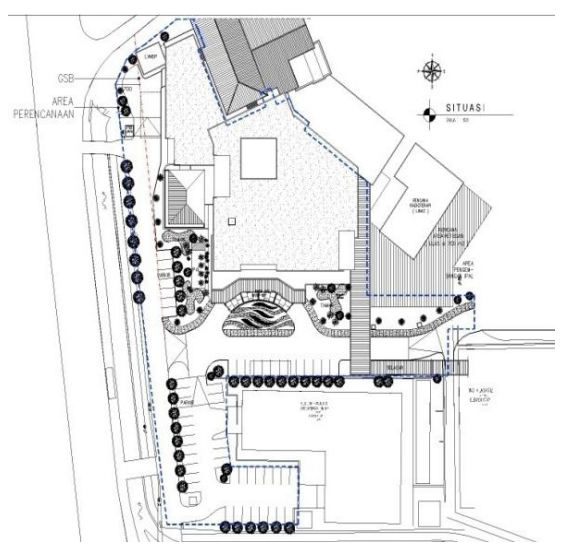

Gambar Situasi NTS

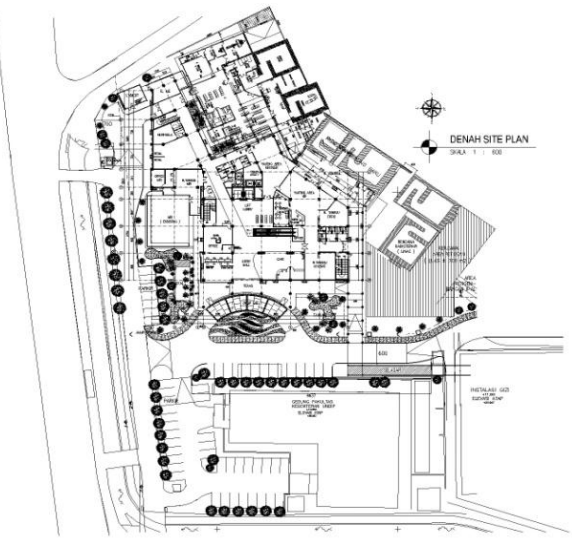

Gambar Site Plan NTS 


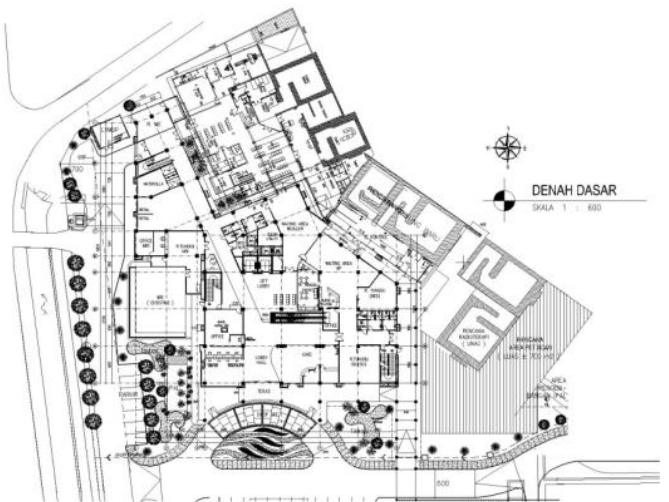

Gambar Denah Lantai Dasar NTS

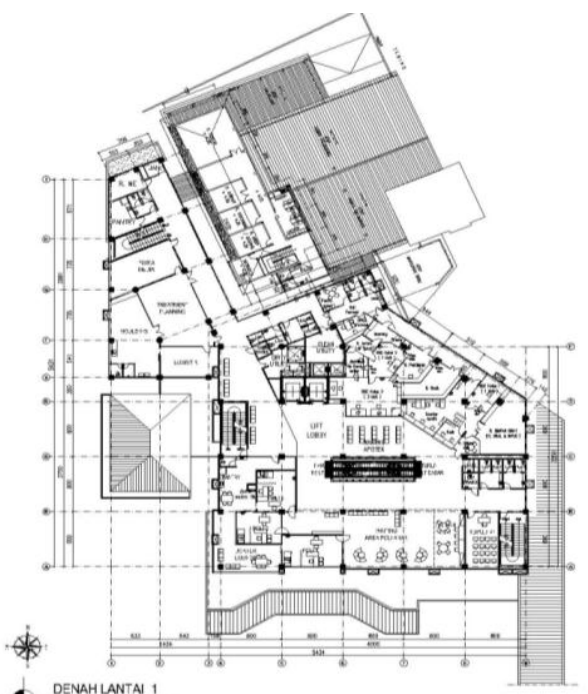

Gambar Denah Lantai 1 NTS

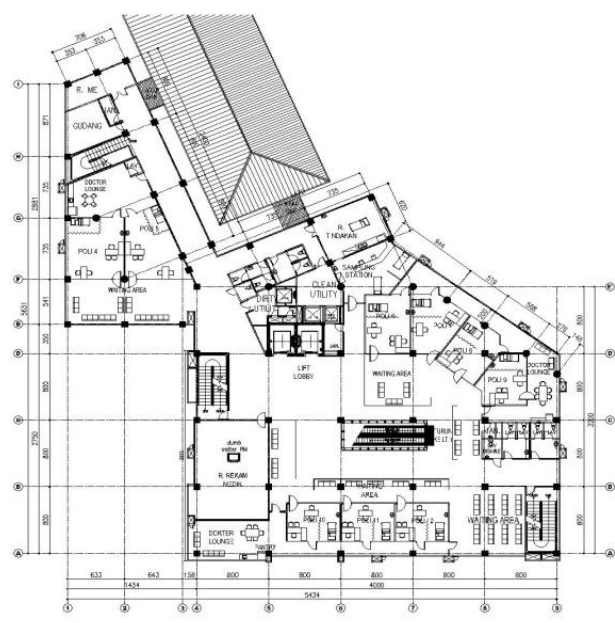

Gambar Denah Lantai 2 NTS

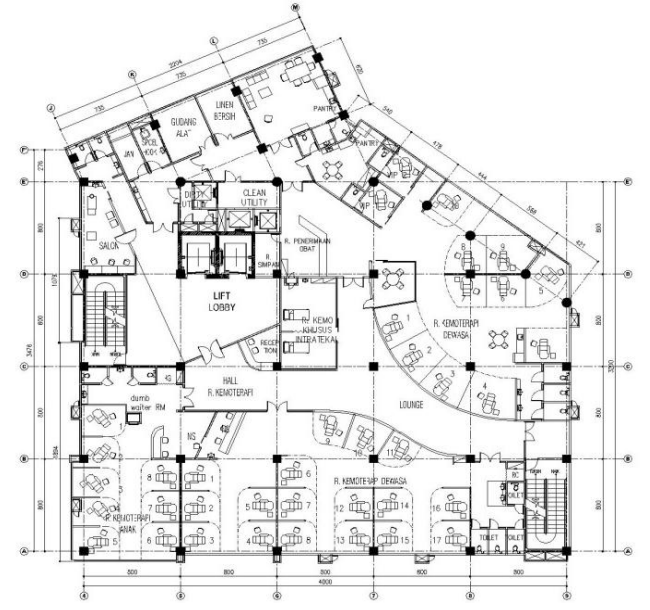

Gambar Denah Lantai 3

NTS
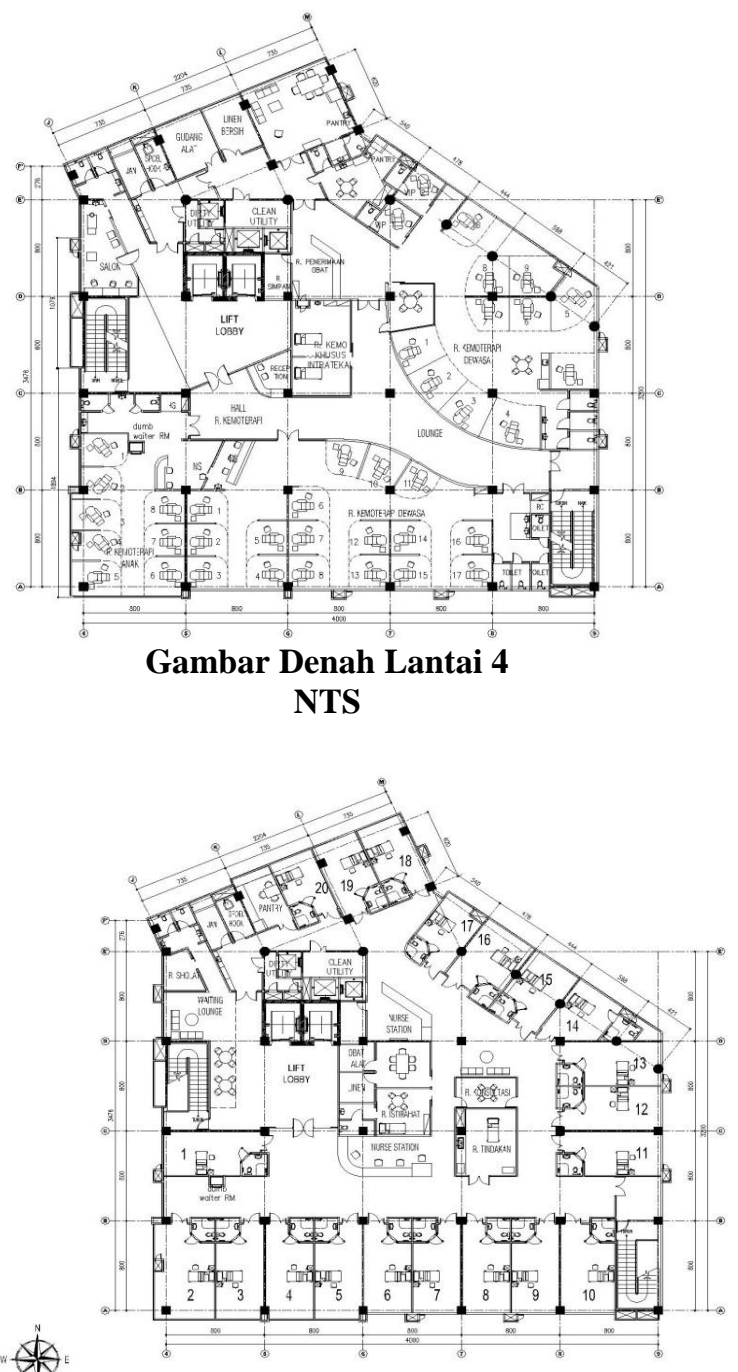

Gambar Denah Lantai 5 NTS 


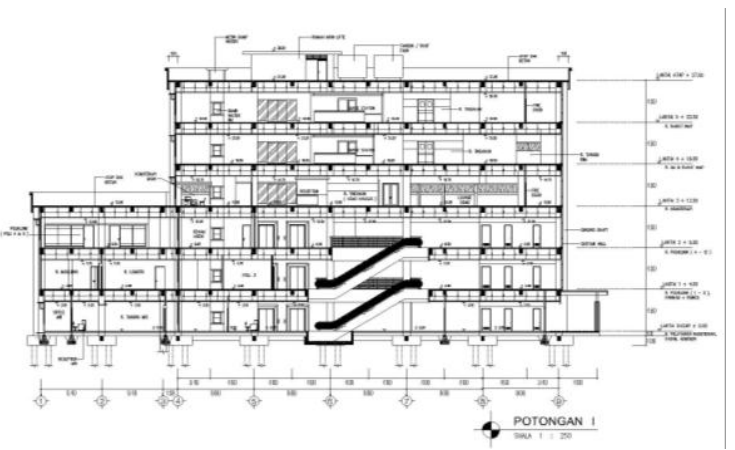

Gambar Potongan 1 NTS

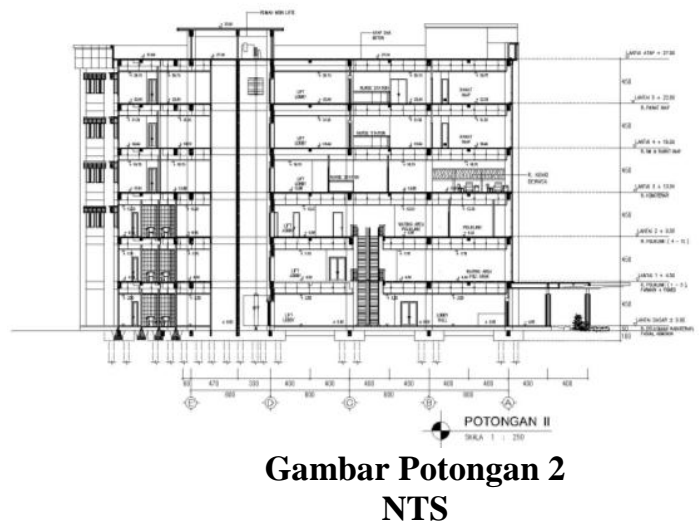

Figur 5. Gambar Pra Rencana Gedung Pusat Onkologi

(Sumber Gambar: Pra Rencana: CV. Aretas, 2017)

\section{Kajian Jenis Ruang}

Analisis, menggunakan metoda saintifik, berkenaan dengan konfigurasi tata ruang dan persyaratan teknisnya dalam menunjang pelayanan medik khusus terutama terkait prosedur pelayanan (treatment) kepada pasien dengan penyakit kanker dalam ruang tersebut pada obyek studi kasus.

Pada tahap ini eksplorasi desain terhadap macam dan jenis ruang dilakukan untuk menemukenali karakteristiknya yang nantinya akan dilihat keterkaitannya (integrasi antar ruang) dan pemenuhan persyaratan teknis bangunan akibat prosedur pelayanan medik yang diberikan.

Pembahasan kajian jenis ruang mengacu lingkup Gedung Pusat Onkologi yang dimaksud di RSUP Dr. Kariadi adalah gabungan antara bangunan eksisting Gedung Radioterapi (2 lantai) dengan Gedung Onkologi baru (6 lantai).

Tiap lantai terdapat ruang dengan karakter pelayanan medik dan penunjang medik sampai pada ruang umum dan service, koneksi antar ruang untuk pola hubungan horizontal dengan koridor sedangkan untuk pola hubungan vertical dengan escalator dan lift, termasuk transport barang dan obat menggunakan lift service maupun jenis dumb waiter.
Dengan demikian karakter bangunan bertingkat tidak menghambat pelayanan kinerja satu atap (komprehensif) untuk pasien penyakit kanker. Namun ruang khusus radioterapi yang mempunyai persyaratan proteksi radiasi tinggi tetap pada posisi lantai dasar. Untuk RSUP Dr. kariadi memanfaatkan keberadaan fasilitas ini dari kondisi eksistingnya yaitu ruang radioterapi menempel bukit untuk proteksi radiasi bagi sekitar ruang. Adapun gedung onkology dibangun melekat pada fasilitas ini untuk memperoleh kondisi pelayanan satu atap bagi pasien penyakit kanker.

Ruang yang ada dalam Gedung Onkology Center mempunyai karakteristik keterkaitan yang erat antara satu ruang dengan ruang lainnya khususnya bila meruapkan rangkaian ruang untuk treatment khusus penyakit kanker (Kementrian Kesehatan Republik Indonesia, 2011)(Weller \& Nickl,2009) yaitu :

1. Ruang Perawatan Radioterapi

Mempunyai rangkaian tersendiri terkait prosedur pelayanan perawatannya yaitu :

Pasien (jalan/stretcher) $\rightarrow$ pendaftaran $\rightarrow$ ruang tunggu $\rightarrow$ konsul /periksa dokter $\rightarrow$ simulasi dan moulding $\rightarrow$ penyinaran radioterapi $\rightarrow$ selesai.

Ruang spesifik dan khusus pada ruang treatment : ruang simulator, moulding dan radioterapi (LINAC dan Cobalt)

2. Ruang Perawatan Kemoterapi

Untuk prosedur pasien tindakan kemoterapi sebagai berikut :

Pasien (jalan/stretcher) $\rightarrow$ pendaftaran $\rightarrow$ ruang tunggu $\rightarrow$ konsul /periksa dokter $\rightarrow$ kemoterapi dan atau intratekal $\rightarrow$ selesai

Ruang khusus pada ruang kemoterapi dan ruang tindakan intratekal dan supplay obat kemoterapi ke ruang kemoterapi

3. R. Farmasi

Ruang farmasi pada pelayanan Gedung Pusat Onkologi tidak sama dengan ruang farmasi pada umumnya, mengingat jenis obat yang diracik maupun didistribusi merupakan jenis obat citostatika (perlakuan khusus karena dosisnya maupun waktu supplay yang harus cepat sampai intake pada pasien - jenis obat yang diramu khusus sehingga stabilitas obat kurang). Akses langsung ke perawatan kemoterapi dan rawat inap maupun rawat jalan menyebabkan ruang farmasi ini harus ditunjang fasilitas distribusi dan pengamanan yang cukup (ruang semi steril maupun proteksi dengan penggunaan bio-safety cabinet saat peramuannya).

Distribusi menggunakan dumb waiter dan lift untuk kondisi distribusi vertikal. 
4. R. Rawat Inap

Rawat inap pada Gedung Onkology Center selain untuk pasien dengan treatment kemoterapi yang lebih dari 4 jam maupun pasien rawat inap regular lainnya juga mempunyai ruang untuk pasien dengan imunitas menurun (pasien induksi) yang harus steril mengingat pasien dalam kondisi rentan. Hal yang unik untuk ruang ini selain prosedur steril dengan ruang antara maupun bentuk prosedur isolasi juga disediakan ruang tunggu khusus bagi keluarga pasien, namun tidak dalam satu ruang dengan pasien, kontak yang disediakan untuk visual dan intercom. Pasien tidak merasa sendiri namun dapat melihat keluarganya. Menunjang untuk kenyamanan bagi pasien namun tidak meninggalkan perlunya isolasi.

\section{HASIL DAN DISKUSI}

Kesimpulan disusun setelah hasil analisis yang berupa keterkaitan jenis ruang yang harus disediakan, integrasinya dalam pelayanan dan yang menunjang terakomodasinya pelayanan medik khusus untuk penderita kanker pada bangunan gedung pusat onkologi Rumah Sakit Kariadi adalah sebagai berikut:

1. Pelayanan untuk pasien kanker (bidang onkologi) memerlukan pelayanan yang komprehensif untuk itu konsep pelayanan satu atap untuk pasien penyakit kanker berupa Gedung Pusat Onkologi menjadi tepat direncanakan dan dirancang secara khusus.

2. Persyaratan khusus pada ruang tindakan harus menjadi perhatian dalam proses desain dan operasionalnya seperti ruang radioterapi (yang memiliki resiko radiasi), ruang kemoterapi yang memiliki pelayanan prosedur khusus bagi pasiennya, maupun rawat inap dengan imunitas menurun juga menjadi ciri khas gedung onkologi.

3. Kinerja pelayanan Gedung Onkologi tergantung pada pelayanan sirkulasinya, karena gedung merupakan bangunan berlantai banyak (6 lantai) maka peran transportasi vertical menjadi utama. Mengacu pada karakteristik pelayanannya maka jenis transportasi vertical yang digunakan mencakup:

- Elevator Pasien

- Elevator Barang

- Eskalator untuk ruang public yang kontinyu

- Dumb Waiter

- Tangga (TanggaDarurat)
- $\quad$ Pneumatic Tube (obat, sampling dan data) - koneksi dengan gedung lain yang terkait (seperti laboratorium)

4. Melihat kondisi lapangan bahwa jumlah pasien kanker cukup banuak maka teknis pelayanan yang lebih terintegrasi dan pengoptimalan peralatan yang dimiliki oleh RSUP Dr. Kariadi menjadi upaya yang sangat signifikan untuk para pasien.

5. Kompleksitas jenis ruang maupun persyaratan masing-masing ruang terutama ruang khusus menjadi perhatian bagi desainer/arsitek dalam konteks desain Gedung Pusat Onkologi secara komprehensif.

\section{REKOMENDASI}

Dengan demikian rekomendasi yang dapat diberikan yaitu bahwasanya desain Gedung Pusat Onkologi merupakan desain pelayanan kesehatan yang relatif rumit karena kekhasan jenis ruang tindakan dan prosedur yang harus dilakukan untuk pelayanan pasien kanker.

Untuk itu hasil penelitian ini dapat digunakan sebagai panduan desain untuk mendukung pemahaman terhadap peran penting pemahaman terhadap jenis ruang atau fasilitas yang terintegrasi serta memenuhi persyaratan teknis medik yang spesifik.

Meskipun mengingat keterbatasan waktu dan lingkup penelitian masih dapat dikembangkan lebih rinci terhadap detail ruang spesifik yang ada sehingga panduan menjadi lebih operasional maupun aplikatif. Diantaranya lebih kepada penekanan prosedur pelayanan atau operasional terhadap masing-masing ruang spesifik yang ada dalam Gedung Pusat Onkologi seperti:
a. Ruang Perawatan Radioterapi
b. Ruang Perawatan Kemoterapi
c. Ruang Farmasi
d. Ruang Rawat Inap (reguler dan Ruang Inap untuk pasien dengan imunitas menurun)

\section{REFERENSI}

Aretas, CV. (2017) Laporan Pra Rencana RS Dr. Kariadi

Global Rancang Selaras. (2017) Laporan Detail Engineering Drawing RS Dr. Kariadi

Fischer, Joachim; Meuser, Philipp (2009) Construction and Design Manual Accessible Architecture, DOM publishers.

Hatmoko, Adi Utomo; Wulandari, Wahju; Alhamdani, Muhammad Ridha; Lionar, Mario Lodeweik. (2015) Arsitektur Rumah Sakit. Yogyakarta, PT.

Kementrian Kesehatan Republik Indonesia (2011) Standar Akreditasi Rumah Sakit, Jakarta 
K. Shleifer, Simone (Editor) (2010), 1000 Details in Architecture, booOs publishers bvba

Laseau, Paul; Tice, James (1992), Frank Lloyd Wright Between Principle and Form, Van Nostrand Reinhold NY

Runciman, W., Hibbert, P., Thomson, R., Van Der Schaaf, T., Sherman, H., \& Lewalle, P. (2009). Towards an International Classification for Patient Safety: Key concepts and terms. International Journal for Quality in Health Care, 21(1),18-26.https://doi.org/10.1093/intqhe/ mzn057.

Sabaruddin, Arief (2013). A-Z Persyaratan Teknis Bangunan, Griya Kreasi (Penebar Swadaya Grup).

Tim K3 RSUP Dr. Kariadi (2015) laporan K3 Dr. Kariadi, Semarang

VA Design Guide-Nuclear (2008). Departement of Veterans Affair, Veterans Health Administration Office of Facilities Management.

-----------, Radioteraphy Facilities: Master Planning and Concept Design Consideration, IAEA HUMAN HEALTH REPORTS No. 10, International Atomic Atomic Agency Vienna, 2014, the IAEA web site: http://www.iaea.org/Publications/index.html.

Weller, Nick; Christine;Nickl, Hans (2009). Hospital Architecture + Design, Braun Publishing AG 